\title{
IGF-1 Attenuates Hypoxia-Induced Atrophy but Inhibits Myoglobin Expression in C2C12 Skeletal Muscle Myotubes
}

\author{
Eva L. Peters ${ }^{1}{ }^{(D)}$, Sandra M. van der Linde ${ }^{1}{ }^{(\mathbb{C})}$, Ilse S. P. Vogel ${ }^{1}$, Mohammad Haroon ${ }^{1}{ }^{(\mathbb{C})}$, \\ Carla Offringa ${ }^{1}$, Gerard M. J. de Wit ${ }^{1}$, Pieter Koolwijk ${ }^{2}$, Willem J. van der Laarse ${ }^{2}$ and \\ Richard T. Jaspers ${ }^{1, *}$ \\ 1 Laboratory for Myology, Faculty of Behavioral and Movement Sciences, \\ Department of Human Movement Sciences, Amsterdam Movement Sciences, \\ Vrije Universiteit Amsterdam, De Boelelaan 1108, 1081 HZ Amsterdam, The Netherlands; \\ el.peters@vumc.nl (E.L.P.); desandra@hotmail.com (S.M.v.d.L.); ilsevogel@gmail.com (I.S.P.V.); \\ m.h.mohammadazam@vu.nl (M.H.); c.offringa@vu.nl (C.O.); g.m.j.de.wit@vu.nl (G.M.J.d.W.) \\ 2 Department of Physiology, Amsterdam Cardiovascular Sciences, VU University Medical Center, \\ De Boelelaan 1108, 1081 HZ Amsterdam, The Netherlands; p.koolwijk@vumc.nl (P.K.); \\ wj.vanderlaarse@vumc.nl (W.J.v.d.L.) \\ * Correspondence: r.t.jaspers@vu.nl; Tel.: +31-20-59-88463
}

Received: 25 July 2017; Accepted: 29 August 2017; Published: 1 September 2017

\begin{abstract}
Chronic hypoxia is associated with muscle wasting and decreased oxidative capacity. By contrast, training under hypoxia may enhance hypertrophy and increase oxidative capacity as well as oxygen transport to the mitochondria, by increasing myoglobin $(\mathrm{Mb})$ expression. The latter may be a feasible strategy to prevent atrophy under hypoxia and enhance an eventual hypertrophic response to anabolic stimulation. Mb expression may be further enhanced by lipid supplementation. We investigated individual and combined effects of hypoxia, insulin-like growth factor (IGF)-1 and lipids, in mouse skeletal muscle C2C12 myotubes. Differentiated C2C12 myotubes were cultured for $24 \mathrm{~h}$ under $20 \%, 5 \%$ and $2 \%$ oxygen with or without IGF-1 and / or lipid treatment. In culture under $20 \%$ oxygen, IGF- 1 induced $51 \%$ hypertrophy. Hypertrophy was only $32 \%$ under $5 \%$ and abrogated under $2 \%$ oxygen. This was not explained by changes in expression of genes involved in contractile protein synthesis or degradation, suggesting a reduced rate of translation rather than of transcription. Myoglobin mRNA expression increased by $75 \%$ under $5 \% \mathrm{O}_{2}$ but decreased by $50 \%$ upon IGF-1 treatment under $20 \% \mathrm{O}_{2}$, compared to control. Inhibition of mammalian target of rapamycin (mTOR) activation using rapamycin restored $\mathrm{Mb}$ mRNA expression to control levels. Lipid supplementation had no effect on Mb gene expression. Thus, IGF-1-induced anabolic signaling can be a strategy to improve muscle size under mild hypoxia, but lowers $\mathrm{Mb}$ gene expression.
\end{abstract}

Keywords: hypoxia; myoglobin; hypertrophy; anabolic signaling; $\mathrm{C} 2 \mathrm{C} 12$; fatty acid; mTOR; mitochondrial biosynthesis; succinate dehydrogenase; myogenic regulatory factors; VEGF

\section{Introduction}

Chronic diseases and aging are conditions associated with a loss in muscle mass and increased fatigability [1]. One of the contributing factors to the deterioration of skeletal muscle may be hypoxia and the chronic disease associated effects resemble those that have been reported in humans after experimental exposure to chronic hypoxia [2-5]. Humans show decreased muscle fiber cross-sectional area, and constant or lower mitochondrial volume, the latter being indicative for a lower oxidative capacity $[3,6,7]$. Similar effects were observed in C2C12 mouse skeletal myotubes, engineered skeletal 
muscle tissue, and in rodents where exposure to hypoxia also reduced time to fatigue during treadmill running [8-15].

One potent way to increase muscle strength is resistance exercise. However, studies on resistance exercise under hypoxia showed contradictory effects. Whereas some showed a blunted hypertrophic response to training under hypoxia $[12,16,17]$, others suggested that training under hypoxia may prevent atrophy and can even enhance hypertrophy and oxidative metabolism [2,18-24]. Insulin-like growth factor (IGF)-1 is well known for its anabolic effects by activation of mammalian target of rapamycin (mTOR) and its downstream effector p70S6K [25], although it is currently unknown whether IGF-1 treatment can oppose hypoxia-induced skeletal muscle atrophy [26-28].

With hypertrophy, the diffusion distance for oxygen to the core of the cell increases and thereby imposes a size constraint on the muscle fiber [29-31]. Myoglobin (Mb) facilitates oxygen diffusion within the cell and serves as an oxygen buffer [32,33]. In hypertrophied muscle fibers and cardiac myocytes working at maximal oxygen uptake $\left(\mathrm{VO}_{2} \mathrm{max}\right)$, increased intracellular oxygen transport via $\mathrm{Mb}$ is required to prevent hypoxic cell cores [30,34]. Therefore, inadequate oxygen supply or hypoxia limits hypertrophy. Increasing $\mathrm{Mb}$ expression may thus serve as a strategy to prevent atrophy under hypoxia and enhance an eventual hypertrophic response to IGF-1 [5].

When hypoxia is combined with exercise, $\mathrm{Ca}^{2+}$ activates calcineurin $(\mathrm{CN})$ [35]. $\mathrm{CN}$ then dephosphorylates myocyte enhancer factor 2 (MEF2) and nuclear factor of activated T-cells (NFAT) to induce translocation of these transcription factors to the nucleus, and subsequent $\mathrm{Mb}$ gene transcription [36]. Indeed, the combination of hypoxia and exercise increased $\mathrm{Mb}$ expression in different animal models as well as in human $[5,35,37,38]$. Activation of the Akt-mTOR pathway causes hyperphosphorylation of NFAT in C2C12 myotubes, which prevented nuclear entry of NFAT and blunted NFAT-c1 activation upon calcium ionophore treatment [26]. It is unclear, however, whether IGF-1-induced mTOR activation also prevents NFAT-induced Mb transcription.

A possible way to enhance $\mathrm{Mb}$ expression in a CN-NFAT independent manner could be lipid supplementation [39]. Indeed, supplementation of poly-unsaturated fatty acids (PUFAs) in patients with chronic obstructive pulmonary disease (COPD) and healthy rats showed marked improvements in exercise capacity [40-43]. In addition, lipid supplementation previously showed effects on genes involved in protein breakdown and mitochondrial biogenesis [44,45]. However, no experimental studies were undertaken to investigate whether increased $\mathrm{Mb}$ expression via a CN-NFAT independent pathway, combined with a hypertrophic stimulus, has synergistic effects on muscle hypertrophy and oxidative capacity under hypoxia.

The aims of this study were therefore to investigate whether: (1) IGF-1 can attenuate hypoxia-induced atrophy; (2) IGF-1 inhibits Mb gene expression by hyperphosphorylation of NFAT; and (3) increased Mb expression via a CN-NFAT independent pathway combined with IGF-1 treatment and hypoxia has synergistic effects on myotube hypertrophy and its regulation.

We hypothesized that IGF-1 antagonizes the atrophic effects of hypoxia in $\mathrm{C} 2 \mathrm{C} 12$ myotubes but inhibits $\mathrm{Mb}$ gene transcription via mTOR-induced hyperphosphorylation of NFAT. Further, we expect that a CN-NFAT independent increase in $\mathrm{Mb}$, induced by lipid supplementation, enhances the hypertrophic effects of IGF-1.

\section{Results}

\subsection{Effects of Hypoxia, IGF-1 and Lipids on Myotube Size}

Culturing for $24 \mathrm{~h}$ under hypoxia caused a decrease in mean myotube diameter $(p<0.01$; Figure $1 \mathrm{a}, \mathrm{b}$ ) by $24 \%$ under $5 \% \mathrm{O}_{2}$ and by $40 \%$ under $2 \% \mathrm{O}_{2}$ compared to $20 \% \mathrm{O}_{2}$. Under $20 \% \mathrm{O}_{2}$, supplementation of IGF-1 increased myotube diameter by $51 \%$. This increase was $32 \%$ under $5 \% \mathrm{O}_{2}$ and hypertrophy was absent under $2 \% \mathrm{O}_{2}$, indicating that at lower oxygen tensions the hypertrophic response was attenuated and eventually blunted. Lipid supplementation had an overall hypertrophic effect $(p=0.04)$ but did not enhance IGF-1-induced hypertrophy. 


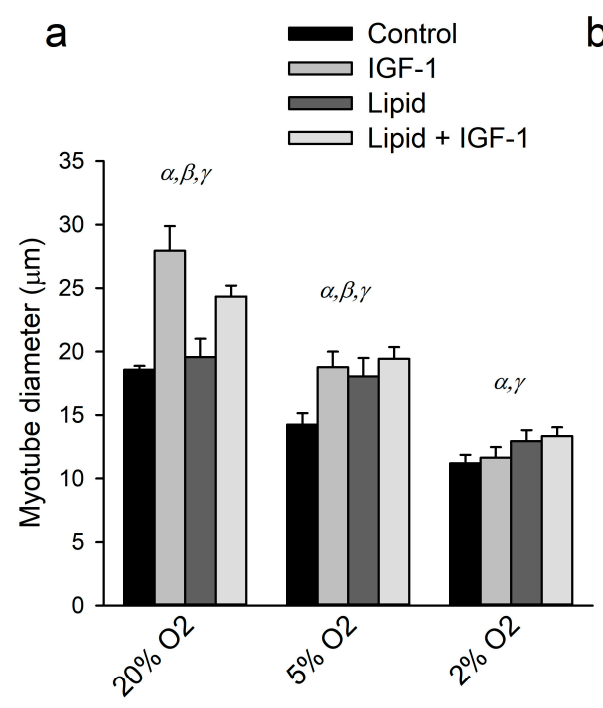

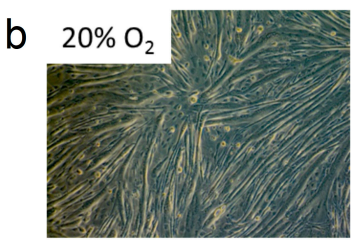
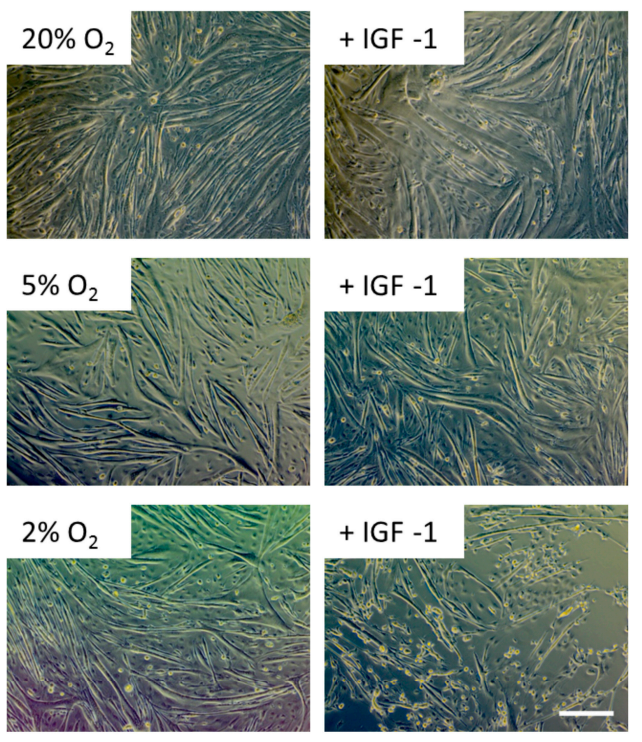

Figure 1. Insulin-like growth factor (IGF)-1-induced hypertrophy is abrogated under hypoxia: (a) fiber diameter of myotubes cultured the last $24 \mathrm{~h}$ of differentiation under different oxygen tensions, with and without supplementation of IGF-1 and lipid; and (b) representative photographs of control- and IGF-1 supplemented cells in all three oxygen tensions. $\alpha$ : significant effect of oxygen tension compared to other $\mathrm{O}_{2}$ tensions; $\beta$ : significant effect of IGF-1 treatment within that specific oxygen tension; $\gamma$ : significant overall effect of lipid supplementation. Values are given as mean $\pm \mathrm{SEM}, n=6$. Scale bar represents $250 \mu \mathrm{m}$.

\subsection{Effects of Hypoxia, IGF-1 and Lipids on Regulators of Protein Synthesis and Degradation}

Next, we looked further into the underlying mechanisms of hypoxia-induced atrophy and the blunted hypertrophic response to IGF-1. Surprisingly, $\alpha$-actin mRNA expression levels increased in hypoxia ( $p<0.01$; Figure 2a), whereas IGF-1 had no effect on $\alpha$-actin mRNA expression $(p=0.37)$. To explain this increase in $\alpha$-actin expression, we investigated mRNA expression levels of MyoD and myogenin, both involved in the regulation of contractile protein gene expression and activation of satellite cells. Both genes had lower expression levels following IGF-1 treatment in all three oxygen conditions ( $p<0.01$ for both; Figure $2 \mathrm{~b}, \mathrm{c}$ ). In addition, oxygen had a significant main effect on MyoD and myogenin expression levels ( $p<0.01$ for both) with expression levels of both being lower under $2 \% \mathrm{O}_{2}$ than those under $20 \%(p<0.01$ and $p<0.05$, respectively) and under $5 \%$ oxygen $(p<0.05$ and $p<0.01$, respectively).

Muscle RING finger 1 (MuRF1) and Muscle atrophy F-box (MAFbx) expression levels decreased following IGF-1 treatment under all three oxygen conditions $(p<0.01$ and $p<0.05$, respectively; Figure 2d,e), while neither MuRF1 nor MAFbx expression levels were changed by lipid supplementation ( $p=0.24$ and $p=0.64$ respectively). The interaction effect between IGF-1 supplementation and oxygen conditions $(p<0.01)$ revealed that, in absence of IGF-1, MAFbx mRNA expression levels increased under $5 \%$ compared to those under $20 \% \mathrm{O}_{2}$, whereas they decreased under $2 \% \mathrm{O}_{2}$ when IGF-1 was added. In presence of IGF-1, MuRF1 mRNA expression levels under $5 \%$ and $2 \% \mathrm{O}_{2}$ were lower than those under $20 \% \mathrm{O}_{2}$ whereas this was not the case in the absence of IGF-1. These results suggest that protein degradation is at most slightly increased under hypoxia and strongly decreased upon IGF-1 supplementation. 
a
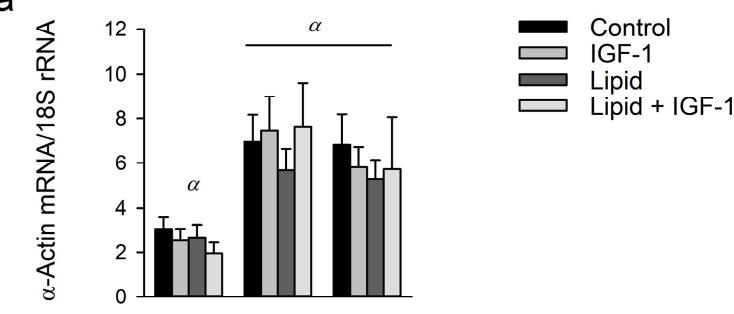

b
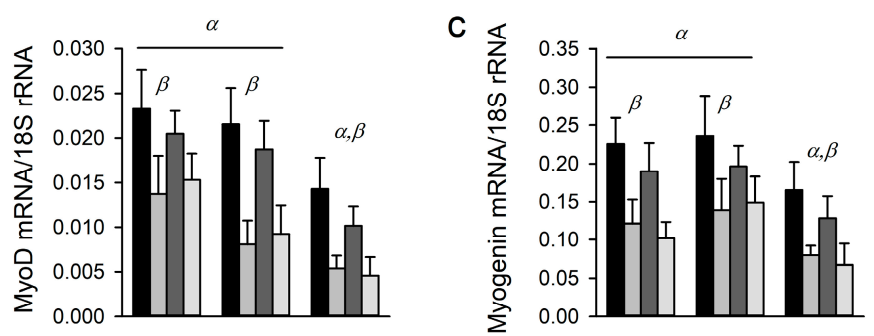

d
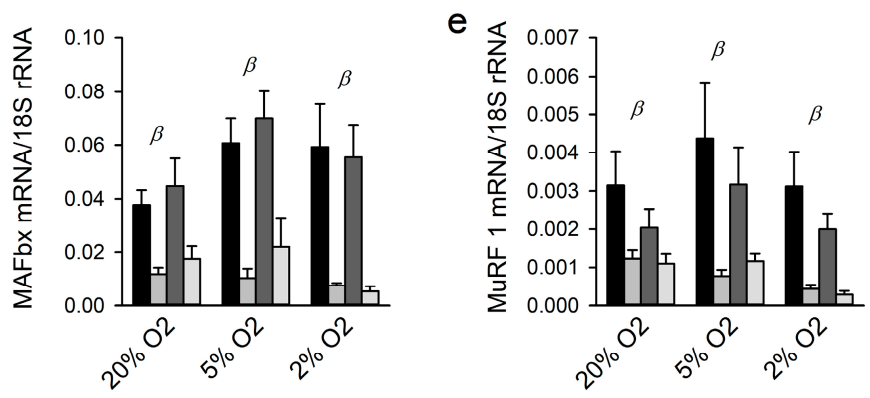

Figure 2. Regulators of protein synthesis are decreased under hypoxia and following IGF-1 supplementation, whereas regulators of protein synthesis are only slightly increased under hypoxia: (a) mRNA expression levels of $\alpha$-actin under different oxygen tensions, with and without $24 \mathrm{~h}$ supplementation of IGF-1 and lipid; $(\mathbf{b}, \mathbf{c})$ mRNA expression levels of differentiation markers MyoD and myogenin; and (d,e) mRNA expression levels of protein degradation markers Muscle Atrophy F-box (MAFbx) and Muscle RING finger 1 (MuRF1). Please note that the interaction for IGF-1 treatment with oxygen tension is not depicted. $\alpha$ : significant effect of oxygen tension compared to other $\mathrm{O}_{2}$ tensions denoted with $\alpha$; $\beta$ : significant overall effect of IGF-1 treatment; $\gamma$ : significant overall effect of lipid supplementation. Although $\beta$ and $\gamma$ designate overall effects, symbols are placed above each oxygen tension for clarity. Values are given as mean $\pm \mathrm{SEM}, n=6$.

\subsection{Effects of Hypoxia, IGF-1 and Lipids on Regulators of Metabolism}

Figure 3 shows mRNA expression levels of genes related to oxidative- or glycolytic metabolism and myosin heavy chain types. Oxidative enzyme capacity as reflected by succinate dehydrogenase (SDH) mRNA expression was decreased under hypoxia in a dose dependent manner $(p<0.001$; Figure 3a), whereas neither lipid supplementation $(p=0.51)$ nor IGF-1 treatment $(p=0.50)$ affected SDH mRNA expression levels.

Peroxisome proliferator-activated receptor- $\gamma$ coactivator (PGC)- $1 \alpha$ was also negatively affected by hypoxia ( $p<0.001$; Figure 3b). IGF-1 treatment caused a decrease in PGC- $1 \alpha$ mRNA expression levels in all three oxygen conditions $(p<0.001)$, whereas lipid supplementation had no effect on PGC-1 $\alpha$ mRNA expression levels $(p=0.26)$.

Glyceraldehyde-3-phosphate dehydrogenase (GAPDH) was measured as a marker of glycolytic metabolism and was increased by lowering oxygen concentrations to $5 \%$ only $(p<0.001$; Figure 3c). Neither IGF-1 nor lipid supplementation altered GAPDH mRNA expression levels $(p=0.73$ and $p=0.53$, respectively). 
We further investigated whether these metabolic alterations coincided with myosin heavy chain (MHC) type switching. Compared to $20 \% \mathrm{O}_{2}$, mRNA expression levels of slow MHC type I increased almost four-fold under $5 \% \mathrm{O}_{2}(p<0.001$; Figure 3d) but decreased upon IGF-1 treatment and lipid supplementation ( $p<0.001$ for both). By contrast, mRNA expression levels of the fast MHC type IIB were increased by IGF-1 treatment ( $p<0.001$; Figure 3e). Relative to $20 \% \mathrm{O}_{2}$ MHC IIB mRNA expression levels were higher under $5 \% \mathrm{O}_{2}$ than under $2 \% \mathrm{O}_{2}(p<0.01)$. In addition, lipid supplementation lowered MHC IIB expression $(p<0.05)$. These results indicate that lowering oxygen levels caused a reduction in oxidative metabolism and that IGF-1 likely favored a shift towards glycolytic metabolism and expression of the fast MHC type IIB.

a

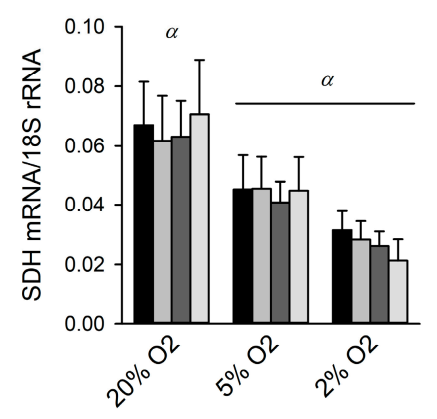

C

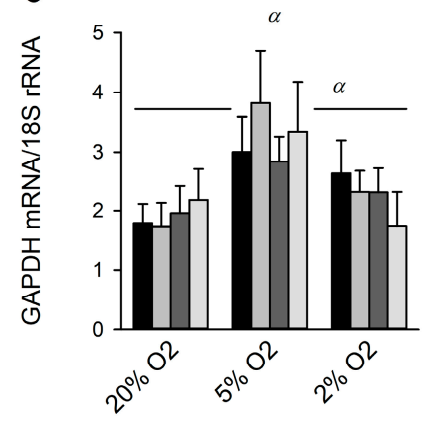

d

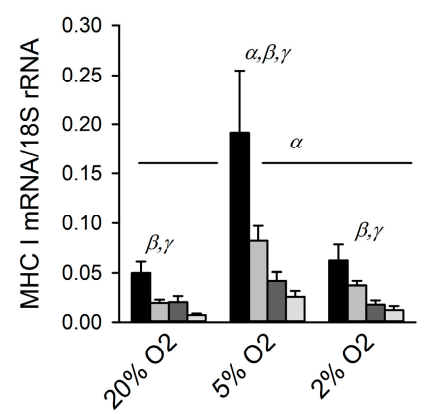

b
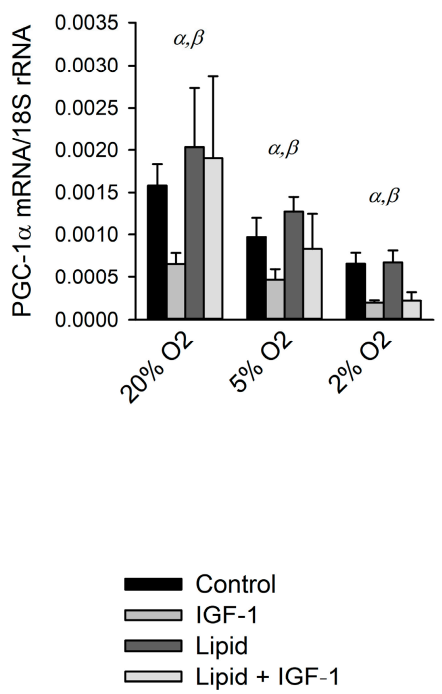

e

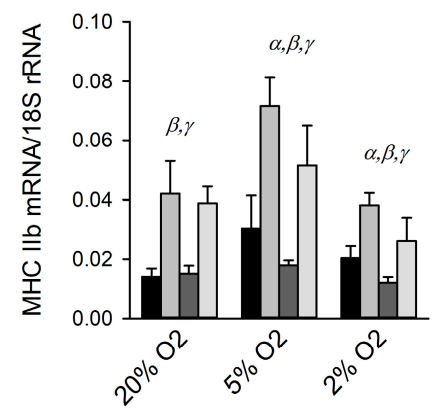

Figure 3. Hypoxia likely causes a reduction in oxidative metabolism and a shift to more glycolytic metabolism: (a,b) mRNA expression levels of SDH and PGC- $1 \alpha$ for myotubes cultured the last $24 \mathrm{~h}$ of differentiation under different oxygen tensions, with and without IGF-1 and lipid as markers of oxidative metabolism; (c) mRNA expression levels of GAPDH was measured as marker of glycolytic metabolism; and (d,e) mRNA expression levels of myosin heavy chain (MHC) I and -IIB were measured as markers for fiber type switching. $\alpha$ : significant effect of oxygen tension compared to other $\mathrm{O}_{2}$ tensions denoted with $\alpha$; $\beta$ : significant overall effect of IGF- 1 treatment; $\gamma$ : significant overall effect of lipid supplementation. Although $\beta$ and $\gamma$ designate overall effects, symbols are placed above each oxygen tension for clarity. Values are given as mean $\pm \mathrm{SEM}, n=6$. 


\subsection{Effects of Hypoxia, IGF-1 and Lipids on Markers of Oxygen Transport}

To investigate the effects of hypoxia, IGF-1 treatment and lipid supplementation on the regulation of oxygen supply to the cells, we investigated mRNA expression levels of vascular endothelial growth factor (VEGF) and $\mathrm{Mb}$, as well as $\mathrm{Mb}$ protein expression as is shown in Figure 4. VEGF expression levels increased under hypoxia $(p<0.001$; Figure 4a). IGF-1 treatment did not show any effect on VEGF expression levels $(p=0.19)$, whereas lipid supplementation decreased VEGF expression levels $(p<0.001)$.
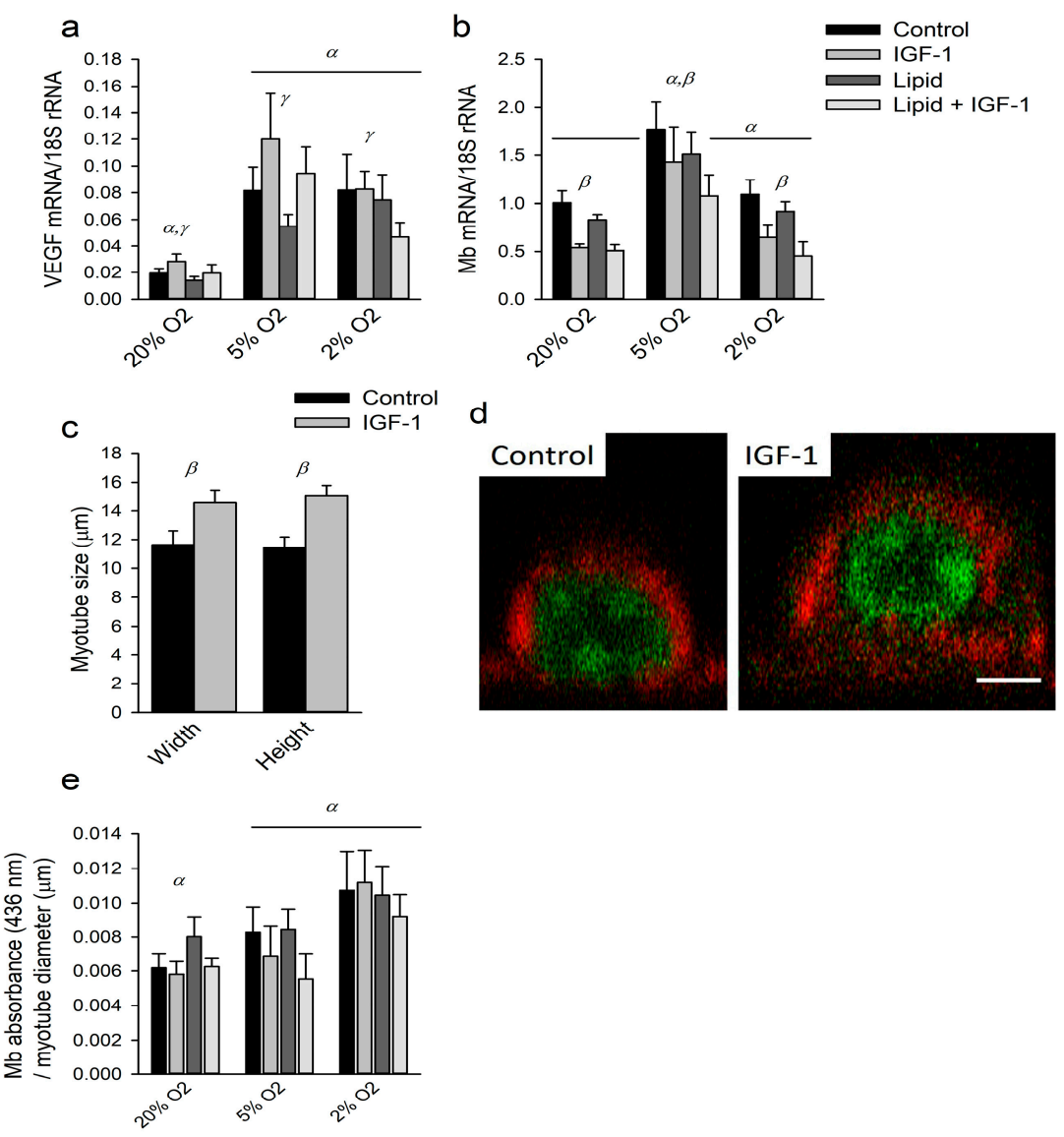

Figure 4. IGF-1 lowers myoglobin $(\mathrm{Mb})$ mRNA expression but not $\mathrm{Mb}$ protein concentration in the cells: $(\mathbf{a}, \mathbf{b})$ mRNA expression levels of vascular endothelial growth factor (VEGF) and Mb for myotubes cultured the last $24 \mathrm{~h}$ of differentiation under different oxygen tensions, with and without IGF-1 and lipid; (c) in a separate experiment, height and width of myotubes was measured ( $n=20$ myotubes); (d) representative examples of cross-sections of individual myocytes live stained in red for F-actin and in green for DNA (scale bar represents $5 \mu \mathrm{m}$ ); and (e) absorbance due to Mb peroxidase activity normalized by myotube diameter as a measure of concentration. $\alpha$ : significant effect of oxygen tension compared to other $\mathrm{O}_{2}$ tensions denoted with $\alpha ; \beta$ significant overall effect of IGF-1 treatment; $\gamma$ : significant overall effect of lipid supplementation. Although $\beta$ and $\gamma$ designate an overall effect, for clarity symbols are placed above every oxygen tension. Values are given as mean \pm SEM, $n=6$.

Oxygen tension had a significant main effect on Mb mRNA expression levels $(p<0.001$; Figure $4 \mathrm{~b})$ which were increased under $5 \% \mathrm{O}_{2}$ compared to $20 \%(p<0.001)$. However, under $2 \% \mathrm{O}_{2}$, expression levels of $\mathrm{Mb}$ mRNA did not significantly differ from those in $20 \% \mathrm{O}_{2}(p=1.00)$. Furthermore, upon IGF-1 treatment, Mb mRNA expression levels decreased in all three oxygen conditions $(p<0.001)$. Lipid supplementation itself did not significantly increase Mb mRNA expression levels $(p=0.1)$ and 
the absence of any significant interaction with IGF-1 indicates that lipid supplementation also could not prevent the IGF-1-induced decrease in Mb mRNA expression.

The $\mathrm{Mb}$ content was measured as absorbance using a calibrated histochemical method based on peroxidase activity [46]. Since absorbance measurements depend on the path length, we verified whether IGF-1-induced hypertrophy occurs equally in all radial directions. The increase in width did not differ from the increase in height $(p=0.34)$. On average, upon IGF-1 treatment myotube width and height increased by $25 \%$ and $33 \%$, respectively $(p<0.001$ for both; Figure $4 c, d)$. This suggests that IGF-1 induced myotube hypertrophy occurred uniformly in radial directions. Since absorbance due to $\mathrm{Mb}$ peroxidase activity is proportional to path length up to at least $16 \mu \mathrm{m}$ [46], Mb absorbance normalized by myotube diameter is taken as a measure of $\mathrm{Mb}$ concentration because Lambert-Beer's law applies.

Despite an increase in $\mathrm{Mb}$ mRNA expression levels in $5 \% \mathrm{O}_{2}, \mathrm{Mb}$ content per myotube did not change in any of the oxygen conditions, nor due to IGF-1 treatment or lipid supplementation (results not shown, $p=0.33, p=0.35$ and $p=0.38$, respectively). However, $\mathrm{Mb}$ concentration was higher under $2 \% \mathrm{O}_{2}$ compared to $5 \%$ and $20 \% \mathrm{O}_{2}(p<0.01)$, whereas IGF-1 and lipid supplementation showed no effects ( $p=0.19$ and $p=0.93$, respectively, Figure 4e).

\subsection{IGF-1 Inhibits Myoglobin mRNA Expression via mTOR Activation}

To investigate whether the inhibition of $\mathrm{Mb}$ expression by IGF-1 was indeed caused by hyperphosphorylation of NFAT via mTOR, we inhibited IGF-1-induced mTOR signaling by rapamycin. $\mathrm{Mb}$ mRNA expression levels relative to control levels are shown in Figure 5. Both IGF-1 and rapamycin showed a significant main effect on $\mathrm{Mb}$ mRNA expression levels ( $p<0.05$ for both). An interaction for IGF-1 $x$ rapamycin $(p<0.05)$ was present, indicative of the opposite effects of both treatments.

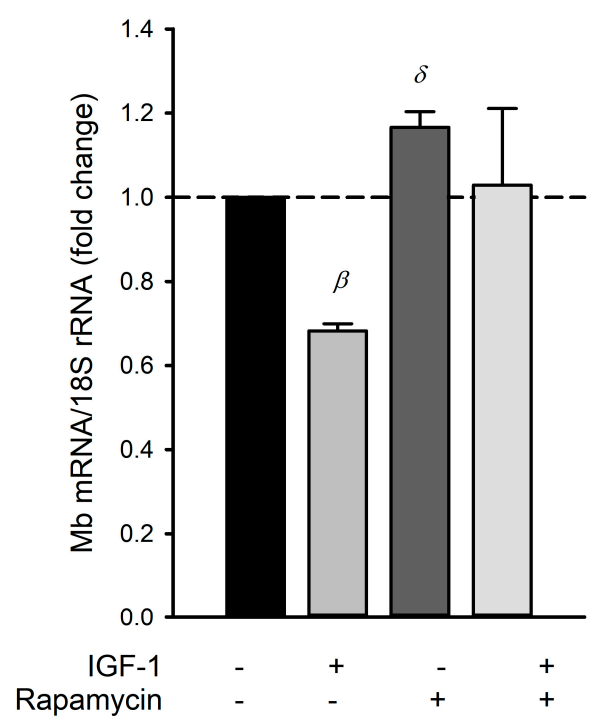

Figure 5. IGF-1 inhibits Mb mRNA expression, which can be restored by inhibition of mammalian target of rapamycin (mTOR). Mb mRNA expression levels relative to control for myotubes treated for $24 \mathrm{~h}$ with IGF-1, myotubes treated with rapamycin or a combination. Myotubes were cultured under $20 \% \mathrm{O}_{2}$. $\beta$ : significant effect of IGF-1 treatment; $\delta$ : significant effect of rapamycin treatment. Values are given as mean \pm SEM, $n=4$.

\section{Discussion}

As expected, myotube diameter decreased under hypoxia, as well as mRNA expression levels of $\mathrm{SDH}$ and its regulator PGC- $1 \alpha$. Surprisingly, the decrease in diameter was accompanied by increased, rather than decreased, $\alpha$-actin mRNA expression levels. MyoD and myogenin are myogenic factors and 
mRNA expression of myogenin is related to $\alpha$-actin promotor activity [47]. We therefore determined mRNA expression levels of $\mathrm{MyoD}$ and myogenin to investigate regulation of protein synthesis at the transcriptional level, and showed a decrease under $2 \%$ but not under $5 \% \mathrm{O}_{2}$, consistent with the literature [48-50]. On the other hand, MAFbx mRNA expression levels increased only under $5 \%$ $\mathrm{O}_{2}$, whereas MuRF1 mRNA expression levels remained unaltered, suggesting only a minor -if anyincrease in protein degradation. Thus, mRNA expression levels of our markers for protein synthesis and degradation cannot explain why $\alpha$-actin mRNA expression levels were increased concomitant with the decrease in myotube diameter.

Alternatively, mRNA translation may be impaired under hypoxia. In vivo, in both rat and human, contradictory results regarding the phosphorylation of Akt, mTOR and p70S6K have been reported [12,51-53]. However, C2C12 myoblasts cultured under hypoxia showed reduced basal Akt-mTOR activation, as well as blunted IGF-1-induced Akt-mTOR activation [50]. In addition, C2C12 myotubes cultured under $2 \% \mathrm{O}_{2}$ for $48 \mathrm{~h}$ showed lower IGF-1-induced phosphorylation of Akt, mTOR and p70S6K after 60 and 180 min of IGF-1 stimulation compared to normoxic controls. Furthermore, in engineered skeletal muscle constructs a reduction in p70S6K phosphorylation following $24 \mathrm{~h}$ culture under $1 \% \mathrm{O}_{2}$ was shown recently [15]. These results indicate that the rate of translation is indeed inhibited by hypoxia $[53,54]$.

\subsection{IGF-1-Induced Hypertrophy Is Limited by Hypoxia}

We investigated whether IGF-1 can prevent hypoxia-induced atrophy. Although IGF-1 induced hypertrophy in myotubes cultured under $20 \%$ and $5 \% \mathrm{O}_{2}$, the amount of hypertrophy under $5 \% \mathrm{O}_{2}$ was $80 \%$ of that under $20 \% \mathrm{O}_{2}$ and thereby only opposed the hypoxia-induced atrophy. In culture under $2 \% \mathrm{O}_{2}$, atrophy was not prevented by IGF-1.

IGF-1 treatment markedly decreased MuRF1 and MAFbx mRNA expression levels under all three oxygen conditions, indicating that protein degradation was indeed decreased. Surprisingly, MyoD and myogenin mRNA expression levels also decreased following IGF-1 treatment, whereas $\alpha$-actin mRNA expression levels remained unaffected by IGF-1. Although generally associated with myogenesis [55,56], doses of IGF-1 similar to the present dose $(13 \mathrm{nM})$ previously diminished myogenic protein expression in $\mathrm{C} 2 \mathrm{C} 12$ myoblasts to almost undetectable levels $24 \mathrm{~h}$ after plating from suspension whereas expression increased above control $72 \mathrm{~h}$ after plating, also dependent on cell density [57]. Thus, the response of MyoD and myogenin to IGF-1 treatment may depend on timing and duration of the treatment and/or on local $\mathrm{PO}_{2}$. Future investigations should reveal whether prolonged anabolic signaling in hypoxia can eventually induce hypertrophy.

\subsection{IGF-1 Inhibits Myoglobin Gene Expression via Activation of mTOR}

In C2C12 myotubes, IGF-1 has been shown to cause hyperphosphorylation of NFAT-c1 by mTOR and thereby IGF-1 prevented calcium ionophore-induced activation of NFAT-c1 [26]. Here, we show that IGF-1 treatment also lowers Mb mRNA expression levels. This is likely due to the hyperphosphorylation of NFAT by mTOR, since inhibition of mTOR by rapamycin increased $\mathrm{Mb}$ mRNA expression levels.

Despite decreased $\mathrm{Mb}$ mRNA expression levels following IGF-1 treatment, the $\mathrm{Mb}$ absorbance due to peroxidase activity was similar for all conditions. However, myotube diameter decreased under hypoxia. Assuming that myotube atrophy also occurred uniformly in all radial directions, we conclude that the concentration of $\mathrm{Mb}$ was increased under $2 \% \mathrm{O}_{2}$, as reflected by a higher $\mathrm{Mb}$ absorbance/diameter ratio. Thus, despite an increase in $\mathrm{Mb}$ mRNA expression under hypoxia, the total content of $\mathrm{Mb}$ per unit of myotube length did not increase and the increase in concentration was only due to myotube atrophy. 


\subsection{Lipid Supplementation Does Not Increase Myoglobin Gene Expression}

We hypothesized that $\mathrm{Mb}$ expression can be increased by lipid supplementation [39]. We found that lipid supplementation had no effect on either Mb mRNA or protein expression. Differences in timing and duration of the exposure may explain the discrepancy between present and previous results $[39,58]$. Particularly in the study by Schlater et al. myotubes were cultured with lipid during seven days of differentiation, whereas, in our study, lipids were present only for the last $24 \mathrm{~h}$ of differentiation. Possibly, lipid supplementation primes skeletal muscle to enhance $\mathrm{Mb}$ expression, which would agree with previous findings in primary myotubes from Weddel seal [58]. In rats fed high-fat diets for 32 weeks, starting at six weeks of age, a positive effect on $\mathrm{Mb}$ expression was also observed indicating that lipid supplementation exerts its effect on $\mathrm{Mb}$ expression not only during myogenesis. It may be that the longer duration of supplementation explains the difference in results of the present study compared to previous research [39,58]. We conclude that one day of supplementation is not sufficient. However, lipid supplementation reduced VEGF mRNA expression. Since VEGF may induce $\mathrm{Mb}$ expression [59], lipid supplementation can have inhibited, rather than stimulated $\mathrm{Mb}$ expression via VEGF signaling.

It should be noted that some studies used albumin as a carrier for the uptake of fatty acids, which could also explain the absence of lipid-induced $\mathrm{Mb}$ expression $[44,60]$. However, the increase in $\mathrm{Mb}$ expression previously reported by Schlater et al. was found without addition of albumin to the culture medium. In addition, we show an effect of lipid supplementation on myotube diameter and mRNA expression levels of VEGF and both MHC types, indicating that supplementation affected gene expression. It remains elusive whether lipid supplementation can induce fiber type switching and explain the effects of lipid supplementation in vivo.

We conclude that the hypertrophic response to IGF-1 is blunted under hypoxia. Although IGF-1 can attenuate hypoxia-induced atrophy of myotubes to a limited extent, it inhibits $\mathrm{Mb}$ mRNA expression. This cannot be circumvented following $24 \mathrm{~h}$ of lipid supplementation.

\section{Materials and Methods}

\subsection{Cell Culture and Myotube Analyses}

C2C12 myotubes were grown for four days in Dulbecco's Modified Eagle's Media (DMEM, Life Technologies, Carlsbad, CA, USA), supplemented with $10 \%$ fetal bovine serum (FBS, Thermo Scientific, Waltham, MA, USA), 1\% Penicillin/Streptomycin (PS, Life Technologies, Carlsbad, CA, USA), and 0.5\% fungizone (Life Technologies, Carlsbad, CA, USA) and kept in a humidified incubator at $37^{\circ} \mathrm{C}, 5 \% \mathrm{CO}_{2}$. Differentiation was induced at 60-70\% confluency by changing the media to DMEM, supplemented with $2 \%$ horse serum (HS, GE Healthcare Life Sciences, Little Chalfont, UK), $1 \%$ PS and $0.5 \%$ fungizone (Life Technologies, Carlsbad, CA, USA), for four days. After 3 days of differentiation, myotubes were cultured for $24 \mathrm{~h}$ under different oxygen tensions $\left(20 \%, 5 \%\right.$ or $\left.2 \% \mathrm{O}_{2}\right)$ using a custom designed hypoxia workstation as described before [61]. Myotubes were cultured in either differentiation medium, or in medium supplemented with IGF-1 (100 ng/mL, Peprotech, Rocky Hill, NJ, USA), a mixture of lipids ( $5 \%$ lipid-supplemented media $(2 \mu \mathrm{g} / \mathrm{mL}$ arachidonic acid, $10 \mu \mathrm{g} / \mathrm{mL}$ each of linoleic, linolenic, myristic, oleic, palmitic and stearic fatty acids), Sigma, St. Louis, MO, USA), or a combination thereof. Rapamycin (2 ng/mL, Bioaustralis, Smithfield NSW, Australia) was added one hour prior to IGF-1 treatment and in $20 \%$ oxygen conditions only.

Four photographs of each well were taken at $10 \times$ magnification after the $24 \mathrm{~h}$ treatment. Diameters were measured in 20 myotubes ( 5 in each image) at 5 equidistant locations along the length of the cell using ImageJ (http:/ / rsbweb.nih.gov/ij/, National Institutes of Health, Bethesda, MD, USA) and taking into account the pixel-to-aspect ratio. All original data can be found in Supplementary Materials. 


\subsection{Live Cell Imaging}

To assess whether IGF-1-induced hypertrophy was equal in all radial directions $\mathrm{C} 2 \mathrm{C} 12$ myotubes were cultured in 8-wells Ibidi-treated plates (Ibidi) as described above and either or not treated with IGF-1 for $24 \mathrm{~h}$. Myotubes were stained in red for F-actin filaments using Sir-Actin $(0.62-2.5 \mu \mathrm{M}$, Cytoskeleton Inc., Denver, CO, USA) and in green for the nucleus using Syto-9 $(200 \mathrm{nM}$, Thermo Scientific, Waltham, MA, USA). Both stains were incubated for $4 \mathrm{~h}$. Verapamil (10 $\mu \mathrm{M}$, Cytoskeleton, Inc., Denver, CO, USA) was added to prevent excretion of the staining by the myotubes. Images were captured using a SP8 STED microscope (Leica microsystems GmbH, Wetzlar, Germany). $3 \mathrm{D}$ reconstructions were created from Z-stacks with $0.3 \mu \mathrm{m}$ spacing. Height and width of the cells were measured in about 20 myotubes in each condition using The Medical Imaging Interaction Toolkit (MITK, http:/ / www.mitk.org, Heidelberg, Germany) at 5 equidistant locations along the length of the myotubes.

\subsection{Myoglobin Concentration}

After culture, while remaining adhered to culture discs, myotubes were fixated for $10 \mathrm{~min}$ using glutaraldehyde (Sigma, St. Louis, MO, USA) [62] and subsequently incubated for $60 \mathrm{~min}$ in a buffer with O-tolidine (Sigma, St. Louis, MO, USA) and T-butylhydroperoxide (Fluka Chemie GmbH, Buchs, Switzerland) [62]. Images were taken at $5 \times$ magnification (Leica DMRB, Wetzlar, Germany). Absorbance was measured at $436 \mathrm{~nm}$. The method was validated using gelatin sections containing known concentrations of horse myoglobin [46]. For each condition 20 myotubes were measured as described above.

\subsection{Quantitative Polymerase Chain Reaction ( $q P C R$ )}

Cells were harvested for RNA isolation in TRIreagent (Life Technologies, Carlsbad, CA, USA) and stored at $-80{ }^{\circ} \mathrm{C}$. RNA was isolated using RiboPure ${ }^{\mathrm{TM}}$ kit (Applied Biosystems, Foster City, CA, USA) and converted to cDNA with high-capacity RNA to cDNA master mix (Applied Biosystems, Foster City, CA, USA). cDNA was diluted $10 \times$ and stored at $-20^{\circ} \mathrm{C}$ until further use. For each gene target $5 \mu \mathrm{L}$ of cDNA was amplified in duplicate using Fast SYBR Green Mastermix (Applied Biosystems, Foster City, CA, USA) on a StepOne Real-Time PCR system (Applied Biosystems, Foster City, CA, USA). Primers are listed in Table 1. Mean cycle thresholds were converted to relative expressions by subtraction of the $18 \mathrm{~S}$ rRNA cycle threshold and determination of $2^{-\Delta \mathrm{Ct}}$ [63].

Table 1. Primers used for PCR analysis. GAPDH glyceraldehyde-3-phosphate dehydrogenase; MAFbx muscle atrophy F-box; Mb Myoglobin; MHC Myosin Heavy Chain; MuRF1 muscle RING finger 1; PGC- $1 \alpha$ peroxisome proliferator-activated receptor- $\gamma$ coactivator- $1 \alpha$; SDH succinate dehydrogenase; VEGF vascular endothelial growth factor.

\begin{tabular}{ccc}
\hline Target $\mathbf{m R N A}$ & Forward & Reverse \\
\hline $18 \mathrm{~S}$ & GTAACCCGTTGAACCCCATT & CCATCCAATCGGTAGTAGCG \\
GAPDH & TGAAGCAGGCATCTGAGGG & CGAAGGTGGAAGAGTGGGAG \\
MAFbx & AGACTGGACTTCTCGACTGC & TCAGCTCCAACAGCCTTACT \\
$\mathrm{Mb}$ & GGAAGTCCTCATCGGTCTGT & GCCCTTCATATCTTCCTCTGA \\
MHC I & AGATCCGAAAGCAACTGGAG & CTGCCTTGATCTGGTTGAAC \\
MHC IIB & CAACTGAGTGAAGTGAAGACC & AGCTGAGAAACCATAGCGTC \\
MuRF1 & GGGCTACCTTCCTCTCAAGTGC & CGTCCAGAGCGTGTCTCACTC \\
MyoD & AGCACTACAGTGGCGACTCA & GCTCCACTATGCTGGACAGG \\
Myogenin & CCCAACCCAGGAGATCATTT & GTCTGGGAAGGCAACAGACA \\
PGC-1 $\alpha$ & ACACAACCGCAGTCGCAACA & GGGAACCCTTGGGGTCATTTGG \\
SDH & GTCAGGAGCCAAAATGGCG & CGACAGGCCTGAACTGC \\
$\alpha-A c t i n$ & GGCCAGAGTCAGAGCAGCAGAAAC & CACCAGGCCAGAGCCGTTGT \\
VEGF & CTGTAACGATGAAGCCCTGGAGTG & GGTGAGGTTTGATCCGCATGATCT \\
\hline
\end{tabular}




\subsection{Statistical Analysis}

Three-way analysis of variance (ANOVA) was performed with factors oxygen tension, IGF-1 and lipid supplementation. Normality of the data was checked using Shapiro-Wilk tests. In the case of non-normality, ANOVA was performed on logarithmic transformed data. Equality of variances was verified using Levene's test. Significant main effects were further investigated using Bonferroni multiple comparisons. Significant interaction effects were followed-up by one-way ANOVA using Bonferroni correction. Values are given as mean \pm standard error of the mean (SEM); $p<0.05$ was considered statistically significant. Unless stated otherwise, $n=6$.

Supplementary Materials: Supplementary materials can be found at www.mdpi.com/1422-0067/18/9/1889/s1.

Acknowledgments: Mohammad Haroon was funded by the European Commission through MOVE-AGE, an Erasmus Mundus Joint Doctorate program (2011-0015). The authors would like to thank Jeroen Kole and René J. P. Musters for excellent help with live cell imaging.

Author Contributions: Sandra M. van der Linde, Ilse S. P. Vogel, Pieter Koolwijk, Willem J. van der Laarse and Richard T. Jaspers conceived and designed the experiments; Eva L. Peters, Sandra M. van der Linde, Ilse S. P. Vogel, Pieter Koolwijk and Willem J. van der Laarse performed the experiments; Eva L. Peters, Sandra M. van der Linde, Carla Offringa, Gerard M. J. de Wit and Mohammad Haroon analyzed data; and Eva L. Peters, Willem J. van der Laarse and Richard T. Jaspers wrote the paper.

Conflicts of Interest: The authors declare no conflict of interest.

\section{Abbreviations}

$\begin{array}{ll}\text { CN } & \text { Calcineurin } \\ \text { COPD } & \text { Chronic Obstructive Pulmonary Disease } \\ \text { DMEM } & \text { Dulbecco's Modified Eagle's Media } \\ \text { FBS } & \text { Fetal Bovine Serum } \\ \text { GAPDH } & \text { Glyceraldehyde-3-phosphate dehydrogenase } \\ \text { HS } & \text { Horse Serum } \\ \text { IGF-1 } & \text { Insulin-like Growth Factor 1 } \\ \text { Mafbx } & \text { Muscle atrophy F-box } \\ \text { Mb } & \text { Myoglobin } \\ \text { MEF2 } & \text { Myocyte Enhancer Factor 2 } \\ \text { MHC } & \text { Myosin Heavy Chain } \\ \text { MITK } & \text { Medical Imaging Interaction Toolkit } \\ \text { mTOR } & \text { Mammalian Target Of Rapamycin } \\ \text { MuRF1 } & \text { Muscle RING finger 1 } \\ \text { NFAT } & \text { Nuclear Factor of Activated T-cells } \\ \text { p70S6K } & \text { p70-S6 Kinase 1 } \\ \text { PGC-1 } \alpha & \text { Peroxisome Proliferator-Activated Receptor- } \gamma \text { Coactivator } 1 \alpha \\ \text { PUFA } & \text { Poly-Unsaturated Fatty Acid } \\ \text { qPCR } & \text { Qualitative Polymerase Chain Reaction } \\ \text { SDH } & \text { Succinate Dehydrogenase } \\ \text { SEM } & \text { Standard Error of the Mean } \\ \text { SR } & \text { Sarcoplasmic Reticulum } \\ \text { VEGF } & \text { Vascular Endothelial Growth Factor }\end{array}$

\section{References}

1. Moylan, J.S.; Reid, M.B. Oxidative stress, chronic disease, and muscle wasting. Muscle Nerve 2007, 35, 411-429. [CrossRef] [PubMed]

2. Bigard, A.X.; Brunet, A.; Guezennec, C.Y.; Monod, H. Skeletal muscle changes after endurance training at high altitude. J. Appl. Physiol. 1991, 71, 2114-2121. [PubMed]

3. Hoppeler, H.; Kleinert, E.; Schlegel, C.; Claassen, H.; Howald, H.; Kayar, S.R.; Cerretelli, P. Morphological adaptations of human skeletal muscle to chronic hypoxia. Int. J. Sports Med. 1990, 11 S 1, S3-S9. [CrossRef] [PubMed] 
4. Green, H.J.; Sutton, J.R.; Cymerman, A.; Young, P.M.; Houston, C.S. Operation everest II: Adaptations in human skeletal muscle. J. Appl. Physiol. 1989, 66, 2454-2461. [PubMed]

5. Jaspers, R.T.; Testerink, J.; Della Gaspera, B.; Chanoine, C.; Bagowski, C.P.; van der Laarse, W.J. Increased oxidative metabolism and myoglobin expression in zebrafish muscle during chronic hypoxia. Biol. Open 2014, 3, 718-727. [CrossRef] [PubMed]

6. MacDougall, J.D.; Green, H.J.; Sutton, J.R.; Coates, G.; Cymerman, A.; Young, P.; Houston, C.S. Operation everest II: Structural adaptations in skeletal muscle in response to extreme simulated altitude. Acta Physiol. Scand. 1991, 142, 421-427. [CrossRef] [PubMed]

7. Howald, H.; Pette, D.; Simoneau, J.A.; Uber, A.; Hoppeler, H.; Cerretelli, P. Effect of chronic hypoxia on muscle enzyme activities. Int. J. Sports Med. 1990, 11, S10-S14. [CrossRef] [PubMed]

8. Elliott, B. The Role of Acute Ambient Hypoxia in the Regulation of Myostatin. Ph.D. Thesis, University of Westminster, London, UK, 2015.

9. Slot, I.G.; Schols, A.M.; Vosse, B.A.; Kelders, M.C.; Gosker, H.R. Hypoxia differentially regulates muscle oxidative fiber type and metabolism in a HIF-1 $\alpha$-dependent manner. Cell. Signal. 2014, 26, 1837-1845. [CrossRef] [PubMed]

10. Li, W.; Hu, Z.F.; Chen, B.; Ni, G.X. Response of C2C12 myoblasts to hypoxia: The relative roles of glucose and oxygen in adaptive cellular metabolism. BioMed Res. Int. 2013, 2013, 326346. [CrossRef] [PubMed]

11. Wüst, R.C.; Jaspers, R.T.; van Heijst, A.F.; Hopman, M.T.; Hoofd, L.J.; van der Laarse, W.J.; Degens, H. Region-specific adaptations in determinants of rat skeletal muscle oxygenation to chronic hypoxia. Am. J. Physiol. Heart Circ. Physiol. 2009, 297, H364-H374. [CrossRef] [PubMed]

12. Chaillou, T.; Koulmann, N.; Simler, N.; Meunier, A.; Serrurier, B.; Chapot, R.; Peinnequin, A.; Beaudry, M.; Bigard, X. Hypoxia transiently affects skeletal muscle hypertrophy in a functional overload model. Am. J. Physiol. Regul. Integr. Comp. Physiol. 2012, 302, R643-R654. [CrossRef] [PubMed]

13. Chaudhary, P.; Suryakumar, G.; Prasad, R.; Singh, S.N.; Ali, S.; Ilavazhagan, G. Chronic hypobaric hypoxia mediated skeletal muscle atrophy: Role of ubiquitin-proteasome pathway and calpains. Mol. Cell Biochem. 2012, 364, 101-113. [CrossRef] [PubMed]

14. Abdelmalki, A.; Fimbel, S.; Mayet-Sornay, M.H.; Sempore, B.; Favier, R. Aerobic capacity and skeletal muscle properties of normoxic and hypoxic rats in response to training. Pflüg. Archiv. 1996, 431, 671-679. [CrossRef]

15. Martin, N.R.W.; Aguilar-Agon, K.; Robinson, G.P.; Player, D.J.; Turner, M.C.; Myers, S.D.; Lewis, M.P. Hypoxia impairs muscle function and reduces myotube size in tissue engineered skeletal muscle. J. Cell. Biochem. 2017, 118, 2599-2605. [CrossRef] [PubMed]

16. Etheridge, T.; Atherton, P.J.; Wilkinson, D.; Selby, A.; Rankin, D.; Webborn, N.; Smith, K.; Watt, P.W. Effects of hypoxia on muscle protein synthesis and anabolic signaling at rest and in response to acute resistance exercise. Am. J. Physiol. Endocrinol. Metab. 2011, 301, E697-E702. [CrossRef] [PubMed]

17. Narici, M.V.; Kayser, B. Hypertrophic response of human skeletal muscle to strength training in hypoxia and normoxia. Eur. J. Appl. Physiol. Occup. Physiol. 1995, 70, 213-219. [CrossRef] [PubMed]

18. Desplanches, D.; Hoppeler, H.; Linossier, M.T.; Denis, C.; Claassen, H.; Dormois, D.; Lacour, J.R.; Geyssant, A. Effects of training in normoxia and normobaric hypoxia on human muscle ultrastructure. Pflüg. Archiv. 1993, 425, 263-267. [CrossRef]

19. Dufour, S.P.; Ponsot, E.; Zoll, J.; Doutreleau, S.; Lonsdorfer-Wolf, E.; Geny, B.; Lampert, E.; Flück, M.; Hoppeler, H.; Billat, V.; et al. Exercise training in normobaric hypoxia in endurance runners. I. Improvement in aerobic performance capacity. J. Appl. Physiol. 2006, 100, 1238-1248. [CrossRef] [PubMed]

20. Zoll, J.; Ponsot, E.; Dufour, S.; Doutreleau, S.; Ventura-Clapier, R.; Vogt, M.; Hoppeler, H.; Richard, R.; Fluck, M. Exercise training in normobaric hypoxia in endurance runners. III. Muscular adjustments of selected gene transcripts. J. Appl. Physiol. 2006, 100, 1258-1266. [CrossRef] [PubMed]

21. Scott, B.R.; Slattery, K.M.; Sculley, D.V.; Dascombe, B.J. Hypoxia and resistance exercise: A comparison of localized and systemic methods. Sports Med. 2014, 44, 1037-1054. [CrossRef] [PubMed]

22. Scott, B.R.; Loenneke, J.P.; Slattery, K.M.; Dascombe, B.J. Blood flow restricted exercise for athletes: A review of available evidence. J. Sci. Med. Sport 2016, 19, 360-367. [CrossRef] [PubMed]

23. Abe, T.; Kearns, C.F.; Sato, Y. Muscle size and strength are increased following walk training with restricted venous blood flow from the leg muscle, kaatsu-walk training. J. Appl. Physiol. 2006, 100, 1460-1466. [CrossRef] [PubMed] 
24. Fujita, S.; Abe, T.; Drummond, M.J.; Cadenas, J.G.; Dreyer, H.C.; Sato, Y.; Volpi, E.; Rasmussen, B.B. Blood flow restriction during low-intensity resistance exercise increases $\mathrm{S} 6 \mathrm{~K} 1$ phosphorylation and muscle protein synthesis. J. Appl. Physiol. 2007, 103, 903-910. [CrossRef] [PubMed]

25. Burnett, P.E.; Barrow, R.K.; Cohen, N.A.; Snyder, S.H.; Sabatini, D.M. RAFT1 phosphorylation of the translational regulators p70 S6 kinase and 4E-BP1. Proc. Natl. Acad. Sci. USA 1998, 95, 1432-1437. [CrossRef] [PubMed]

26. Rommel, C.; Bodine, S.C.; Clarke, B.A.; Rossman, R.; Nunez, L.; Stitt, T.N.; Yancopoulos, G.D.; Glass, D.J. Mediation of IGF-1-induced skeletal myotube hypertrophy by PI(3)K/Akt/mTOR and PI(3)k/Akt/GSK3 pathways. Nat. Cell Biol. 2001, 3, 1009-1013. [CrossRef] [PubMed]

27. Glass, D.J. Skeletal muscle hypertrophy and atrophy signaling pathways. Int. J. Biochem. Cell Biol. 2005, 37, 1974-1984. [CrossRef] [PubMed]

28. Bodine, S.C.; Stitt, T.N.; Gonzalez, M.; Kline, W.O.; Stover, G.L.; Bauerlein, R.; Zlotchenko, E.; Scrimgeour, A.; Lawrence, J.C.; Glass, D.J.; et al. Akt/mTOR pathway is a crucial regulator of skeletal muscle hypertrophy and can prevent muscle atrophy in vivo. Nat. Cell Biol. 2001, 3, 1014-1019. [CrossRef] [PubMed]

29. Van der Laarse, W.J.; des Tombe, A.L.; Lee-de Groot, M.B.E.; Diegenbach, P.C. Size principle of striated muscle cells. Neth. J. Zool. 1998, 48, 213-223. [CrossRef]

30. Van Wessel, T.; de Haan, A.; van der Laarse, W.J.; Jaspers, R.T. The muscle fiber type-fiber size paradox: Hypertrophy or oxidative metabolism? Eur. J. Appl. Physiol. 2010, 110, 665-694. [CrossRef] [PubMed]

31. Van der Laarse, W.J.; Diegenbach, P.C.; Elzinga, G. Maximum rate of oxygen consumption and quantitative histochemistry of succinate-dehydrogenase in single muscle fibers of xenopus laevis. J. Muscle Res. Cell Motil. 1989, 10, 221-228. [CrossRef]

32. Wittenberg, B.A.; Wittenberg, J.B. Myoglobin-mediated oxygen delivery to mitochondria of isolated cardiac myocytes. Proc. Natl. Acad. Sci. USA 1987, 84, 7503-7507. [CrossRef] [PubMed]

33. Wittenberg, B.A.; Wittenberg, J.B.; Caldwell, P.R. Role of myoglobin in the oxygen supply to red skeletal muscle. J. Biol. Chem. 1975, 250, 9038-9043. [PubMed]

34. Peters, E.L.; Offringa, C.; Kos, D.; van der Laarse, W.J.; Jaspers, R.T. Regulation of myoglobin in hypertrophied rat cardiomyocytes in experimental pulmonary hypertension. Pflug. Arch. 2016, 468, 1697-1707. [CrossRef] [PubMed]

35. Kanatous, S.B.; Mammen, P.P.A.; Rosenberg, P.B.; Martin, C.M.; White, M.D.; DiMaio, J.M.; Huang, G.; Muallem, S.; Garry, D.J. Hypoxia reprograms calcium signaling and regulates myoglobin expression. Am. J. Physiol. Cell Physiol. 2009, 296, C393-C402. [CrossRef] [PubMed]

36. Kanatous, S.B.; Mammen, P.P.A. Regulation of myoglobin expression. J. Exp. Biol. 2010, 213, $2741-2747$. [CrossRef] [PubMed]

37. Vogt, M.; Puntschart, A.; Geiser, J.; Zuleger, C.; Billeter, R.; Hoppeler, H. Molecular adaptations in human skeletal muscle to endurance training under simulated hypoxic conditions. J. Appl. Physiol. 2001, 91, 173-182. [PubMed]

38. Terrados, N.; Jansson, E.; Sylven, C.; Kaijser, L. Is hypoxia a stimulus for synthesis of oxidative enzymes and myoglobin? J. Appl. Physiol. 1990, 68, 2369-2372. [PubMed]

39. Schlater, A.E.; de Miranda, M.A.; Frye, M.A.; Trumble, S.J.; Kanatous, S.B. Changing the paradigm for myoglobin: A novel link between lipids and myoglobin. J. Appl. Physiol. 2014, 117, 307-315. [CrossRef] [PubMed]

40. Broekhuizen, R.; Wouters, E.F.; Creutzberg, E.C.; Weling-Scheepers, C.A.; Schols, A.M. Polyunsaturated fatty acids improve exercise capacity in chronic obstructive pulmonary disease. Thorax 2005, 60, 376-382. [CrossRef] [PubMed]

41. Peoples, G.E.; McLennan, P.L. Dietary fish oil reduces skeletal muscle oxygen consumption, provides fatigue resistance and improves contractile recovery in the rat in vivo hindlimb. Br. J. Nutr. 2010, 104, 1771-1779. [CrossRef] [PubMed]

42. Peoples, G.E.; McLennan, P.L. Long-chain n-3 DHA reduces the extent of skeletal muscle fatigue in the rat in vivo hindlimb model. Br. J. Nutr. 2014, 111, 996-1003. [CrossRef] [PubMed]

43. Henry, R.; Peoples, G.E.; McLennan, P.L. Muscle fatigue resistance in the rat hindlimb in vivo from low dietary intakes of tuna fish oil that selectively increase phospholipid n-3 docosahexaenoic acid according to muscle fibre type. Br. J. Nutr. 2015, 114, 873-884. [CrossRef] [PubMed] 
44. Huang, F.; Wei, H.; Luo, H.; Jiang, S.; Peng, J. EPA inhibits the inhibitor of $\kappa \mathrm{B} \alpha(\mathrm{I} \kappa \mathrm{B} \alpha) / \mathrm{NF}-\kappa \mathrm{B} / \mathrm{muscle}$ RING finger 1 pathway in C2C12 myotubes in a PPAR $\gamma$-dependent manner. Br. J. Nutr. 2011, 105, 348-356. [CrossRef] [PubMed]

45. Garcia-Roves, P.; Huss, J.M.; Han, D.H.; Hancock, C.R.; Iglesias-Gutierrez, E.; Chen, M.; Holloszy, J.O. Raising plasma fatty acid concentration induces increased biogenesis of mitochondria in skeletal muscle. Proc. Natl. Acad. Sci. USA 2007, 104, 10709-10713. [CrossRef] [PubMed]

46. Lee-de Groot, M.B.E.; des Tombe, A.L.; van der Laarse, W.J. Calibrated histochemistry of myoglobin concentration in cardiomyocytes. J. Histochem. Cytochem. 1998, 46, 1077-1084. [PubMed]

47. Marsh, D.R.; Carson, J.A.; Stewart, L.N.; Booth, F.W. Activation of the skeletal $\alpha$-actin promoter during muscle regeneration. J. Muscle Res. Cell Motil. 1998, 19, 897-907. [CrossRef] [PubMed]

48. Di Carlo, A.; de Mori, R.; Martelli, F.; Pompilio, G.; Capogrossi, M.C.; Germani, A. Hypoxia inhibits myogenic differentiation through accelerated myod degradation. J. Biol. Chem. 2004, 279, 16332-16338. [CrossRef] [PubMed]

49. Yun, Z.; Lin, Q.; Giaccia, A.J. Adaptive myogenesis under hypoxia. Mol. Cell Biol. 2005, 25, 3040-3055. [CrossRef] [PubMed]

50. Ren, H.; Accili, D.; Duan, C. Hypoxia converts the myogenic action of insulin-like growth factors into mitogenic action by differentially regulating multiple signaling pathways. Proc. Natl. Acad. Sci. USA 2010, 107, 5857-5862. [CrossRef] [PubMed]

51. De Theije, C.C.; Langen, R.C.; Lamers, W.H.; Schols, A.M.; Kohler, S.E. Distinct responses of protein turnover regulatory pathways in hypoxia- and semistarvation-induced muscle atrophy. Am. J. Physiol. Lung Cell Mol. Physiol. 2013, 305, L82-L91. [CrossRef] [PubMed]

52. Favier, F.B.; Costes, F.; Defour, A.; Bonnefoy, R.; Lefai, E.; Bauge, S.; Peinnequin, A.; Benoit, H.; Freyssenet, D. Down regulation of Akt/mammalian target of rapamycin pathway in skeletal muscle is associated with increased REDD1 expression in response to chronic hypoxia. Am. J. Physiol. Regul. Integr. Comp. Physiol. 2010, 298, R1659-1666. [CrossRef] [PubMed]

53. Costes, F.; Gosker, H.; Feasson, L.; Desgeorges, M.; Kelders, M.; Castells, J.; Schols, A.; Freyssenet, D. Impaired exercise training-induced muscle fiber hypertrophy and Akt/mTOR pathway activation in hypoxemic patients with copd. J. Appl. Physiol. 2015, 118, 1040-1049. [CrossRef] [PubMed]

54. Arthur, P.G.; Giles, J.J.; Wakeford, C.M. Protein synthesis during oxygen conformance and severe hypoxia in the mouse muscle cell line C2C12. Biochim. Biophys. Acta 2000, 1475, 83-89. [CrossRef]

55. Rosenthal, S.M.; Cheng, Z.Q. Opposing early and late effects of insulin-like growth factor I on differentiation and the cell cycle regulatory retinoblastoma protein in skeletal myoblasts. Proc. Natl. Acad. Sci. USA 1995, 92, 10307-10311. [CrossRef] [PubMed]

56. Miyake, M.; Hayashi, S.; Sato, T.; Taketa, Y.; Watanabe, K.; Hayashi, S.; Tanaka, S.; Ohwada, S.; Aso, H.; Yamaguchi, T. Myostatin and myod family expression in skeletal muscle of IGF-1 knockout mice. Cell. Biol. Int. 2007, 31, 1274-1279. [CrossRef] [PubMed]

57. Layne, M.D.; Farmer, S.R. Tumor necrosis factor- $\alpha$ and basic fibroblast growth factor differentially inhibit the insulin-like growth factor-i induced expression of myogenin in C2C12 myoblasts. Exp. Cell Res. 1999, 249, 177-187. [CrossRef] [PubMed]

58. De Miranda, M.A., Jr.; Schlater, A.E.; Green, T.L.; Kanatous, S.B. In the face of hypoxia: Myoglobin increases in response to hypoxic conditions and lipid supplementation in cultured weddell seal skeletal muscle cells. J. Exp. Biol. 2012, 215, 806-813. [CrossRef] [PubMed]

59. Van Weel, V.; Deckers, M.M.; Grimbergen, J.M.; van Leuven, K.J.; Lardenoye, J.H.; Schlingemann, R.O.; van Nieuw Amerongen, G.P.; van Bockel, J.H.; van Hinsbergh, V.W.; Quax, P.H. Vascular endothelial growth factor overexpression in ischemic skeletal muscle enhances myoglobin expression in vivo. Circ. Res. 2004, 95, 58-66. [CrossRef] [PubMed]

60. Van der Vusse, G.J. Albumin as fatty acid transporter. Drug Metab. Pharm. 2009, 24, 300-307. [CrossRef]

61. Nauta, T.D.; Duyndam, M.C.A.; Weijers, E.M.; van Hinsbergh, V.M.W.; Koolwijk, P. HIF-2 $\alpha$ expression regulates sprout formation into $3 \mathrm{D}$ fibrin matrices in prolonged hypoxia in human microvascular endothelial cells. PLOS ONE 2016, 11, e0160700. 
62. Van Beek-Harmsen, B.J.; Bekedam, M.A.; Feenstra, H.M.; Visser, F.C.; van der Laarse, W.J. Determination of myoglobin concentration and oxidative capacity in cryostat sections of human and rat skeletal muscle fibres and rat cardiomyocytes. Histochem. Cell Biol. 2004, 121, 335-342. [CrossRef] [PubMed]

63. Nagelkerke, A.; Mujcic, H.; Wouters, B.; Span, P.N. $18 \mathrm{~S}$ is an appropriate housekeeping gene for in vitro hypoxia experiments. Br. J. Cancer 2010, 103, 590. [CrossRef] [PubMed] 